\title{
1. Changing geographies of the state: themes, challenges and futures
}

\author{
Sami Moisio, Andrew E.G. Jonas, Natalie Koch, \\ Christopher Lizotte and Juho Luukkonen
}

\section{$1.1 \quad$ INTRODUCTION}

This is the era of the state. Almost all terrestrial space of the earth is claimed by a state or several states. However, contemporary states are different from each other in many respects, while the concept of the state itself has distinct connotations and meanings in different geographical contexts. States differ in terms of their population and the size of their territory within which they seek to 'master' space. The relative political and economic weight of states differ, too. Internally, states may be categorized as 'weak' or 'strong' with regard to the legitimacy they enjoy among their populace, as well as how well they function within the borders of their jurisdiction. Some may even have semi-sovereign territories within their borders, such as Native American tribal reservations in the United States, or break-away states controlled by secessionist movements as in Georgia or Moldova.

Governments that speak in the name of a given state struggle with a similarly diverse range of issues. The president of the Democratic Republic of Congo seeks to root out corruption, and improve the quality of roads and street lighting. At the same time, state leaders in Northern Europe are seldom concerned with how providing such physical infrastructure might pertain to the visibility and legitimacy of their governments. Instead, they are struggling with low fertility rates and ageing populations that make it difficult to maintain the existing 'infrastructural power' (Mann 1984) of their 'welfare state'. Given that the histories, development paths, institutional structures and contemporary political issues of states vary considerably, the modern state can be understood as a kind of ideal. As an ideal, the state denotes an effort to territorialize political power around a 'state-society' and to establish clear boundaries between the inside and outside of a state.

Since the late nineteenth century, the ideal of the state has been nurtured and maintained in social scientific education and knowledge production. Also since the late nineteenth century, the classical division of labour between the social sciences has been associated with the bifurcation of the state apparatus into sectors. According to the ideal division of labour, sociologists examine societies within states; political scientists scrutinize the state as a political system; international relations (IR) interrogates interstate relations; scholars in administrative sciences study the functioning of state-related administrative systems; and jurisprudence investigates laws as manifestations of the historically contingent 'wills' of the state. For a long time, geographers mapped out the physical and cultural features of a given state. In the mainstream social sciences, the state is still often approached as a 'nation-state' with a national economy and a society as self-evident objects of state intervention. In sum, academic social science has largely reified the state as a territorial idea and ideal. 


\section{Handbook on the changing geographies of the state}

The Handbook on the Changing Geographies of the State: New Spaces of Geopolitics addresses the geographies of the state and how the power of the state brings together territory and populace. Our perspective is critical in the sense of not taking the state as a self-evident object of analysis. Rather, the individual chapters analyse the production, constitution and transformation of the state as a spatial and political form of social organization, as well as how state power operates spatially and manifests in various state-orchestrated projects and strategies. The idea is hence not to reify the state as an ideal political community, but to examine it as a historically contingent spatial expression of political power.

In this chapter, we aim to introduce the reader to some basic information and concepts underpinning geographical approaches to the state. The chapter proceeds as follows. In Section 1.2, we make a rudimentary mapping of some of the geographical approaches to the state before the 1970s, while Section 1.3 considers some more recent approaches. In Section 1.4 , we reflect upon 'methodological globalism' as one of the challenges in a geographical study of the state as a dynamic socio-spatial organization. Section 1.5 outlines research topics that merit attention in future research on the changing geographies of the state.

\subsection{A SHORT HISTORY OF THE GEOGRAPHIES OF THE STATE}

The discipline of geography has long served the interests of the state, ranging from educating teachers about national problems and mapping out its territorial features, resources and qualities, and prospects for growth and expansion. Since the late nineteenth century in particular, geographers have produced knowledge that has been at least potentially useful in either reworking the domestic economic and social spaces of the state or in extending the power of the state beyond its borders. The 'actual' impact of the discipline in constructing and consolidating the modern state is impossible to assess, however. The theoretical foundation of academic geography in the nineteenth century, as well as the canonical works of some of the key figures of the discipline during the early twentieth century, nonetheless reveal intimate connections between the discipline of geography and the state.

The state-centred approaches of Friedrich Ratzel, Rudolf Kjellén, Halford Mackinder and, later, Isaiah Bowman all signal close connections between geographical knowledge and aspirations to state power. From these classical roots, the study of geography was explicitly developed as an aid to statecraft (Parker 1982), while also entrenching a form of epistemological state-centricity within the discipline. The intimate relationship between geography and state power continued after the Second World War, albeit in new forms over the course of the twentieth century. Through their work on spatial and urban planning as well as regional development, many academic geographers in Europe and beyond explicitly contributed to the spatial constitution through applied work, which routinized the 'state' as an object of regional planning and development.

Prior to the 1980s, explicit attempts to theorize the state from a geographical perspective were rare, but determinist perspectives prevailed in the first half of the twentieth century. That is, the state was commonly understood as if it were not only bound to earth but also determined by it (Heffernan 2000). The most influential advocates of this approach in early political geography were Friedrich Ratzel in Germany and Rudolf Kjellén in Sweden, who took their inspiration from evolutionary thinking. In their idealist perspective, the state was a living organism, dependent on external environmental circumstances. Citizens and land together 
formed a natural whole, they argued, and each state was said to have a distinct national culture determined by the natural environment. Ratzel and Kjellén's efforts to theorize the state were rooted in biological fetishism and scientism - the belief that the methods and concepts of physical and biological sciences are equally appropriate for all disciplines - and were not uncommon within European academic circles in the late nineteenth and early twentieth centuries. This environmental determinism persisted into the first half of the twentieth century, when state development and the existence of different kinds of states were explained as the result of the natural environment. US-based Derwent Whittlesey $(1939$, p. 7), for instance, asserted that 'the basic political pattern, that of states, corresponds in varying degrees with the several patterns of natural environment'.

After the Second World War, some scholars began to conceptualize the state from a kind of mechanical perspective. They examined the territorial consolidation and fragmentation of states under forces not emanating from environmental circumstances. Richard Hartshorne (1950), for example, analysed the territorial consolidation and fragmentation of the state as resulting from what he called centripetal and centrifugal forces. Centripetal forces, such as a well-founded and widely shared 'state-idea', bind the state together as a spatial entity. Centrifugal forces, such as the challenging physical form of a state's territory or the diversity of collective identities (which can be 'ethnic', 'religious' or other kinds of groups), potentially pull the state apart. Functionalist or mechanical theories, like Hartshorne's, presuppose some kind of stable territorial dimension of a state, while also failing to analyse the agency of different societal actors who operate through the state in a given historical conjuncture. As with the determinist approaches before them, these newer theories continued to fail in recognizing the social forces and conflicts that actually produce and reproduce the territory and populace of the state.

Jean Gottmann $(1951,1952)$ also sought to overcome naturalism, idealism and descriptiveness in developing a geographical analysis of the state in the early 1950s. A contemporary of Hartshorne, he instead argued that the partitioning of the world into political entities, primarily states, was conditioned by two forces that work in opposite directions. First, the circulation of ideas, peoples and commodities and suchlike is a force that causes instability. Second, the circulation of iconography, such as cultural symbolism and related national traditions and systems of belief that constitute and maintain collective spatial identities, tend towards stability. For Gottmann, the balance between iconography and circulation delineates the openness or closure of the system of territorial states at a given historical conjuncture. He thus argued, 'geography demonstrates that the main partitions observed in the space accessible to men are not those in the topography or in the vegetation but those that are in the minds of the people' (Gottmann 1951, p. 164). Gottmann (1961) further develops his perspective on spatial transformation in his book Megalopolis. Here, he articulates a shift from the system of states to a system of city-networks, which he saw as stemming from the kind of functional needs of 'real communities'. This argument would later become popular among all kinds of globalization boosters, innovation gurus and scholars on 'connectography' (Khanna 2016), who often argue that cities and city-networks are more functional than territorial states in the global economy (Ohmae 1993) or that global governance should be increasingly based on cities and their innovative leaders rather than states (Barber 2013).

Such theoretical openings created by Gottmann are why some have even suggested that he was 'political geography's first real intellectual' (Agnew 2002, p. 18). Be that as it may, the state has long been the taken-for-granted territorial unit of society that structures research 
questions, observations and results in academic geography - contributing to the reification of the state as a clearly delineated entity, characterized by its 'national' inside and 'international' outside (see Agnew 1994). In many ways, this challenge persists today, especially as it overlaps with other idealized cultural-political categories, such as the 'nation'. Thus 'methodological nationalism' (see Koch 2020) and 'embedded statism' (Taylor 2003) have long defined geographic approaches to the state - though the situation has shifted dramatically since the 1980s (for an overview of theories of the state in geography prior to the 1980s, see Clark and Dear 1984).

\subsection{TOWARDS SOCIAL THEORETICAL GEOGRAPHIES OF THE STATE}

Why does the state exist? Whose interests does it serve? What is the relationship between economic and political power in the context of the state? What is the historical relationship between the state and capitalism? How are different kinds of elites entangled with the state? How have techniques of state-orchestrated spatial governance changed over time? What should the state do and how should it be developed as a spatial enterprise? What is the role of bureaucracy in reproducing the state? How has the capitalist state been transformed over the past decades and how does state power manifest itself spatially today? What is the relationship between the territorial state and the transnational hubs and flows of money capital, talent and ideas that characterize contemporary neoliberal globalization? These are the kinds of fundamental questions that researchers of the geography of the state have been examining since the 1980s.

In the early 1980s, Ron Johnston (1982, p. 1) argued that geographers 'have paid little attention to the state and have not subjected it to rigorous analysis'. This situation changed dramatically in the 1980 s, when human geographers began to engage with social theory. If the earlier scholarship had analysed the state either from environmentalist or mechanical (functionalist) perspectives, the social theoretical geographical analysis of the state explicitly engaged with state theory and political economy (for an early account, see e.g. Taylor 1982). The changing geography of the state was now examined in relation to broader societal change and economic development. The territory of the state no longer signalled a sort of passive physical background or side-product to more fundamental societal developments. Instead, state territory and territoriality were approached as distinctly political processes. From this point onward, geographers and other spatially attuned social scientists have conceptualized state spatiality as a fundamental dimension of social, cultural, political-economic and geopolitical processes (Moisio 2019).

The contested territorialization of political power around the state is now an important topic in human geography and beyond. Recent studies emphasizing contextuality, relationality and contingency have sought to denaturalize the state as an ontological category of analysis. In these studies, the state is conceptualized as a constantly changing set of relations that extend beyond present political conditions, hierarchically scaled structures of governance and territorial boundaries. Accordingly, the state is studied primarily as 'a particular way of being and relating' (Ince and Barrera de la Torre 2016, p. 13).

Figure 1.1 illustrates some dimensions of the state as a geographical phenomenon. Population, territory and state apparatus are obviously key constituents of the state. These 


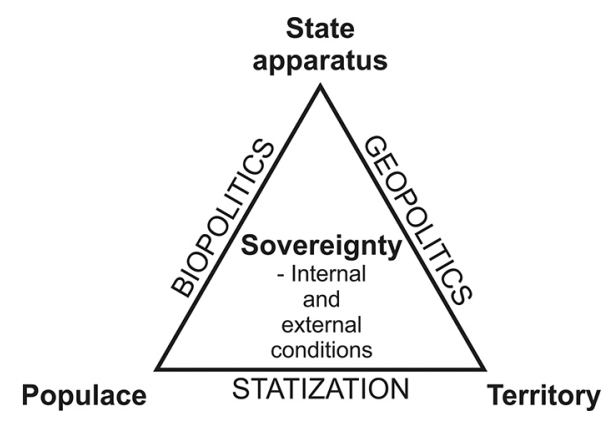

Figure $1.1 \quad$ The state as a geographical expression of political power

parts are, however, conjoined and only analytically separable. The state apparatus can be understood as a set of (banal) bureaucratic practices, as an embodiment of bureaucratic 'state work' and as a field of interbureaucratic conflicts and contestation. The state apparatus is also a site of tensions that emanate from struggles between all kinds of social forces that seek to operate through the state. The state exercises both biopolitical and geopolitical power that can be understood as particular modes of social regulation. These forms of power, in turn, affect the relationship between the populace and the territory - and ultimately ossify in and through particular regimes of capital accumulation and state sovereignty (Agnew 2005).

The multi-layered nature of the state mentioned above is important to recognize in a space-sensitive analysis of the capitalist state. It shows that the state is an inescapably fluid and pluri-centred ensemble that both conceals and reveals different contradictions (cf. Sharma and Gupta 2006). The state can thus be conceptualized as an ongoing process of 'state work' and 'state effects' rather than a static thing. To grapple with the complexity that this theorization entails, we sketch below several key threads in how contemporary geographers have sought to do so: understanding the state as a social relation, as an effect, as a (gendered) social construction and as a social organization under neoliberalization.

\subsubsection{The State as a Social Relation and the Geographies of Regulation}

Since the 1980s, many geographers have taken their inspiration from various forms of historical materialism. This structuralist perspective highlights the nature of the state as a relational social organization. Viewed through this lens, the strategies, calculations and interactions of state management and capitalists come together in the context of the state. Capitalists need the regulative power of the state for several reasons, most importantly but not solely to enable accumulation. At the same time, however, the power and legitimacy of a given state's management is dependent on the generation of economic value in the process of capital accumulation (see, Block 1987) - not least to secure tax revenues. In other words, to maintain the power of the state, state management has to focus on "guaranteeing and safeguarding a "healthy" accumulation process upon which it depends' (Offe and Ronge 1982, p. 250). A structural interdependence between the state and capital thus defines the state in capitalism. Even though the management of a capitalist state embodies a particular autonomy from the fragmented capital class, the state nonetheless tends to guarantee the basis of capitalist society.

The Greek social theorist Nicos Poulantzas (1978, p. 129) famously argues that the state is 'the specific material condensation of a relationship of forces among classes and class 
fractions'. Viewed thus, the state is conceptualized as a social relation: a terrain, source and outcome of political strategies (Jessop 1990). Accordingly, the capitalist economy and society result in different groups - classes and class fractions - with different and partly antagonistic interests. The clash of these interests may involve counter-strategies and tactics of fractions. This is the reason why state power is inescapably 'relational' (Jessop 2008). To prevent the collapse of the existing societal order, the state apparatus organizes social classes in a way that includes the interests of relevant fractions and classes into the regulation of society, without tearing down class society as such. Social relations are hence 'condensed' in the state apparatus in a way that grants influence to all relevant groups (and particularly to the hegemonic fraction) to pursue their interests.

Regulation theory follows some of these basic tenets of materialism to provide a stylized conceptual frame for examining the temporal evolution of capitalist growth and crises (for a comprehensive overview, see Jessop and Sum 2006). This approach is premised on an insight that the general tendencies of capitalism can be modified in a number of ways, and these modifications produce different 'phases' of capital accumulation. The concept of regime of accumulation stands for a phase of capitalist evolution in which the schema of social reproduction is in 'harmony' and in which capital accumulation takes place in a more or less crisis-free environment. The regime of accumulation brings together the dominant forms of economic growth and distribution, as well as modes of social regulation. The functional coupling of these at the scale of the state is often conceived as a prerequisite for a stable regime of accumulation to exist (Peck and Tickell 1992), while also forming a more or less consensual hegemonic project that guarantees the internal unity of the state (Jessop and Sum 2006, p. 98). Regulation theory also emphasizes how capitalism requires an intensive 'extra-economic' management of the populace by the state in terms of reproduction, skills, capacities, orientations and loyalties. Partial and temporary as they may be (Jessop and Sum 2006), these forms of social regulation work to avert the inherent crisis tendencies of capitalism, while also 'internalizing' the inherent crisis tendencies of the process of capital accumulation.

The most discussed shift in regulation theory is the one between the Fordist and the post-Fordist regimes of accumulation. Fordism unites certain institutional mechanisms for reproducing semi-skilled labour, wage relations, and forms of mass production of standardized goods and related consumption (Jessop 1992). Demanding a specific state-society relationship to confine capital circuits within national borders, Fordism was produced by a particular kind of state. This was historically based on a 'national' compromise between organized labour, the state apparatus and corporate capital (Harvey 1990), and related Keynesian ideas regarding the management of the 'national economy' through managing demand and redistribution. The Fordist mode of accumulation began to unravel in the 1970s, however, and was gradually replaced by 'flexible' processes dealing with labour, finance, production and consumption. With circuits of capital no longer confined within state borders, this 'post-Fordist' regime of accumulation hastens the geographical mobility of financial capital and highlights entrepreneurialism, the role of skilled labour and the idea of spatial competition, including the international competitiveness of states, regions and cities. It is defined by the growing importance of cities in the accumulation process that occurs through global value chains, as well as the increased power of financial services and financialization more generally.

The geographical take on regulation theory is concerned with how space, social regulation and accumulation come together, and how they represent a particular kind of 'geography of shifts'. In other words, this research examines ties between changing regimes of capital 
accumulation and states' spatial patterning (cf. Scott 1988). Geographers have shown how the state, as a social relation, is the result of practices related to accumulation and social regulation that obtain a certain spatial fixity or what Harvey (1985) calls 'structured coherence'. Spatial fixity, in turn, structures social practices at a given time. For example, if the Fordist mode of regulation manifests itself as particular national spatial patterning ('national' division of labour and particular 'national' systems of redistribution), the post-Fordist regime of flexible accumulation results in a sort of transnational state with new patterning of uneven development. Moreover, geographers have argued that there exists a series of state-specific and region-specific couplings (variegations) of accumulation systems and modes of social regulation both in the context of Fordism and post-Fordism, and that the coming together of systems of accumulation and social regulation must also be scrutinized in the context of local states and regions, as well as urban politics (Lauria 1997).

One key insight of geographical regulation theory is that uneven geographical development is one of the forces that may lead to the breakdown of the existing regimes of accumulation. One of the recent geographical debates on the state therefore touches on contemporary processes of knowledge-intensive capitalism that produce striking forms of uneven development. Indeed, as geographers have shown, the post-Fordist knowledge-based economy is productive of and is produced through new spaces of the state, including new 'global' urban spaces and urban subjectivities (Moisio 2018c). And if cities have been developing from a managerial to an entrepreneurial form since the 1980s (Harvey 1989), the same can be said about the state. The neoliberalizing entrepreneurial city and the neoliberalizing entrepreneurial 'innovation state' are co-constituted phenomena. This process has fundamentally highlighted the role of major cities and city-region urban spaces in fostering states' international competitiveness (Jonas 2013; Rossi 2017; Moisio 2018b; Luukkonen and Sirviö 2019; Olds 2001). Many of these state-led boosterist projects have focused explicitly on knowledge-based economization, which recent geographical analysis has traced to processes whereby the state is constantly reterritorialized both socially and spatially to better respond to the assumed new logics of capital accumulation, as well as its contradictions (Koch 2018a; Moisio 2018a). As these processes continue to shift, the co-constitution of the 'national state' and 'local state' in the context of reproducing capitalism will remain an important theoretical and empirical question long into the future.

\subsubsection{The State as an Effect}

The state, conceived of as a coherent entity separate from society, has proved a remarkably elusive object of analysis. Geographers have thus sought to conceptualize the state and state territory as an effect of social practices. This approach is premised on a few key theorems regarding the nature of the state. The British sociologist Philip Abrams (1988, pp. 82, 75-6) argues that the processes and relations that make up the 'palpable nexus of practice and institutional structure centred in government' do not result in the object of the state, which is 'an essentially imaginative construction', but only in the pervasive idea of the state which legitimizes domination. Accordingly, the state is a powerful spatial imaginary and a mystifying idea, an abstract-formal object that comes into being as a structuration within political practice. The French philosopher Michel Foucault (2007, p. 144) similarly argues that the state is only 'a composite reality and a mythicized abstraction'. For him, 'the nature of the institution of the state is a function of changes in practices of government, rather than the converse' 
(Gordon 1991, p. 4). Viewed thus, concrete institutions and practices of state institutions and related discourses about the state are 'real', but there is no state 'essence' that exists beyond social practices. The state here is conceptualized as a political 'artefact', an effect that is made out of processes, which involve both discursive and material components (Mitchell 2002, p. 82; see also Lemke 2007; Mitchell 1999).

A theoretical perspective that highlights the everyday nature of the state redirects attention from the assumed 'intentionality' of state power, typical in the historical materialist approach, to the operation of state power in the micro-geographies of the state. Research on this kind of 'state work' underlines three interrelated issues. First, that the primacy of the state is constantly reproduced in banal bureaucratic practices. Second, the sphere of mundane practices is the primary field on which individuals experience the state or learn something about the state. Third, the statization of social life involves the state-orchestrated gathering of knowledge regarding the mundane lives of population itself. Overall, approaching the state as an effect has allowed geographers to overcome the persistent state/civil society binary through inquiry into the everyday spaces of stateness. These quotidian micro-geographies - the 'everyday prosaics of stateness' (Painter 2006) - point not only to the inescapably uncertain and potentially unexpected spatial outcomes of state-related actions, but also to the spatial unevenness of state effects.

The prosaic geographies of stateness have been explored in various studies on everyday state formation (e.g. Ballvé 2012; Staeheli et al. 2012; Neves Alves 2019), everyday nationalism (e.g. Jones and Merriman 2009; Benwell et al. 2019), the embodied presences of the state (e.g. Prokkola and Ridanpää 2015; Secor 2007), as well as on the affective implications and constituents of the state (e.g. Woodward 2014). By focusing on the 'ordinary', these studies have foregrounded the experiences, subjectivities and emotions of individuals drawn into the orbit of the state. They do not imply, however, that macro-geographies such as global economic fluctuations, financial crises or international diplomacy have become irrelevant. Rather, this work underlines that all kinds of 'small matters' such as policy practices or the experiences and emotions of state personnel have significant implications for the workings of state apparatus. The doings and sayings of prominent political leaders still matter greatly, but the doings, sayings and emotions of the 'petty bureaucrats' of state apparatus are also an essential part of the construction and performance of stateness (e.g. Kuus 2015; Jones 2007; Medby 2018). The goal of the work on the state effect is thus to make visible 'the intensification of the symbolic presence of the state across all kinds of social practices and relations' (Painter 2006, p. 758). In short, the statization of social life (and space) proceeds through and thus also depends on quotidian practices undertaken by citizens and state officials alike.

What the state actually means to government officials, those involved in various government programmes and projects, or citizens, is drastically shaped through the repetitive, routine and 'ordinary' bureaucratic procedures of the state (Sharma and Gupta 2006). Given that the legitimacy of the state as an embodiment of social power is dependent on what the state actually means to the citizens of a state, it is essential to ask how the state comes to be experienced, encountered and reimagined by the population of a given state. Moreover, a close investigation of the 'actually existing' bureaucratic authority of state should also pay attention to how different government programmes and state policies are enacted in daily routines by state bureaucrats such as officials, teachers and health-care professionals, for instance. These enactments are highly interesting also in the context of transnationalized state apparatus: how state bureaucrats enact particular globally circulating policy models and knowledges remains an 
important topic in the geographical investigation of the state. It is equally important to notice that because the existence of the state in people's lives is dependent on the banal practices of state bureaucracies, these bureaucracies potentially become sites of cultural contestation.

Bureaucratic authority plays a pivotal role in the 'territory work' (Moisio and Luukkonen 2017) of the state. Bureaucratic practices offer important insights for understanding how 'state territory' is delimited, internally and jurisdictionally ordered, and how it takes on the appearance of existing as a coherent functional and bureaucratic whole (Bourdieu 1999). The emphasis on the bureaucratic authority of the state signals that the territory of the state should be conceptualized as a relational space, a set of bureaucratic processes that together have territory effects. For state territory to exist, it must be measured, analysed, addressed and objectified through bureaucratic knowledge that grasps it in its entirety (Hull 2012). Mapping and surveying the territory of the state is thus about enabling the state to see and govern different people, phenomena and processes (Hannah 2000, 2009; Kivelä 2018; Painter 2010; Rose-Redwood 2012; Tyner 2018). As this work shows, the simple act of imagining the territory of the state as a coherent whole requires forms of knowledge that constitute it as a delimited 'unit' or block of space. To sustain the state territory effect, the delimitation, contiguity and coherence of political space must be constantly reproduced through mundane governmental technologies and associated practices. This 'territory work' perspective to the state combines the idea of state territory as a particular type of political technology for controlling space and populations with the role of political agency in the production of territory as an 'object' - an effect of networked social practices (Moisio and Luukkonen 2017).

\subsubsection{The State as Socially Constructed and Gendered}

Constructivist studies of the politics of identity and the geographies of nationalism form one branch of the geographies of the state. In this approach, the ideology of nationalism and the discursive practices of nations can be understood as important 'constituents' of the state and state power. Social constructivist examinations of nation building, nationalism and national identities became increasingly popular in human geography in the early 1990s, as scholars began to take their inspiration from cultural sociology, cultural theory and discourse studies. Benedict Anderson's (1983) concept of 'imagined communities' became a central theoretical frame applied to analysing how nations and national identities are constructed through representations across geographical contexts. While this early work rightly and readily analysed the social construction of national identities, it often stopped at the moment of deconstruction and failed to directly engage with interdisciplinary state theory debates.

Constructivist research has taken new forms since the 1990s, however. For the contemporary scholars, one important task is to demonstrate how seemingly 'apolitical' social practices related to nation are essential to perpetuating state power. The contemporary constructivist scholarship crosses into many topics, but is most commonly encountered in political geography today in efforts to analyse nationalism, identity politics, geopolitical cultures, borders and bordering practices and more (for an early account, see e.g. Paasi 1996). Largely positioned within the subfield of critical geopolitics, this research shows how nationhood and statehood are imagined, consumed and reproduced through popular media like comic books (Dittmer 2005), film (Funnell and Dodds 2017), television (Jones 2014), mainstream news and satire (Falah et al. 2006; Holland and Levy 2018) and sport (Koch 2013, 2015a). This work also focuses our attention on the entanglement of the 'nation' and the 'state', which scholars have 
explored around themes like religion and the military - both of which are treated as central to national identity construction and the statization of society through a range of national institutions and related practices (Bernazzoli and Flint 2010; Woodward 2000). Drawing inspiration from both Judith Butler's (1990) work on performance and Anderson's (1983) work on 'imagined communities', this research aligns with other critical research in nationalism studies to show how the 'nation' is a performed and embodied identity construction (Edensor 2002; Mayer 2000; Yuval-Davis 1997).

Geographers working on the production and reconstruction of the nation have also drawn from Michael Billig's (1995) Banal Nationalism, which articulated an approach to nationalism focused on the banal elements of its symbology, performance, rhetorics and everydayness that directed attention in nationalism studies away from commonplace analyses of nationalism as resulting from 'postcolonial' anxiety in the non-West or as a 'wartime' phenomenon in the West. Instead, work on banal nationalism has approached it as a global phenomenon that is rooted in the mundane, everyday performances of the state and nation-ness, which must be constantly reproduced (Koch and Paasi 2016).

Developing in tandem with research on the state effect, feminist branches of constructivist geography has offered many insights fundamental to critical theories of the state. This strand of research is rooted in the key feminist rejection of masculinist definitions of politics, predicated on a distinction between the 'private' and the 'public'. This premise is important in the subfield of critical geopolitics, for example, which took much of its early inspiration from feminist international relations scholars' efforts to retheorize the state (Dowler and Sharp 2001, p. 166; see e.g. Enloe 1988; MacKinnon 1989), and continues to be influenced by feminist geography today (Dittmer and Bos 2019; Dixon and Marston 2011).

Feminist scholars had long interrogated state processes and strategies that manifest in the 'private' and 'everyday'. An important principle in such an approach is to decentre the state as a 'national' fixed territory within which sovereignty is smoothly performed. Feminist scholars often destabilize the state as an a priori object of analysis, and rather conceptualize 'state power' as diffuse and pervasive (Chouinard 2004). In so doing, they underline that the private, informal and everyday are key spaces through which state power operates. By refusing to take for granted the public/private divide, and giving more attention to the everyday state, this approach opens up a number of significant research topics and research questions. Rather than treating the state and civil society as two distinct spheres, feminist approaches to the state illustrate how embedded power relations position individuals and groups of people in different hierarchical relations, but ultimately work to cast the state as an imagined collective actor. And yet, as this work shows, it is within the 'intimate' spaces of life that the power of the state is not only condensed but also potentially challenged (Smith 2020).

Feminist geography examines the social aspects of nation building and state building. For feminist scholars, bodies signify an essential scale at which the nation is enacted and state-orchestrated geopolitical processes resonate. This work has 'embodied' the state, and demonstrated how the state is constantly performed in all sorts of social practices ranging from the extra-economic to the economic (Dixon 2015; Dowler and Sharp 2001; Mountz 2003; Smith 2020), as well as the gendered nature of state bureaucratic practices (Tynen 2020). Feminist-inspired scholarship thus challenges the conventional analysis which views the state as a coherent political entity that exists independent of configurations of the everyday and related gendered social practices, while also showing how state performances and imaginaries reproduce patriarchal relations in the most mundane ways (Staeheli et al. 2004). 
Feminist geographers have also investigated the state as a set of institutions and institutional practices that are gendered, racialized and classed - shifting attention from the world of production to the processes of social reproduction that help maintain the capitalist state (Mitchell et al. 2003; Winders and Smith 2019). Viewed thus, the state is a form of potential domination - a complex mixture of social practices that are potentially spatially discriminating and marginalizing (McDowell 1999). The focus may be, for instance, on how certain identities are privileged in state strategies and how the structures of the state tend to reinforce gender biases, as well as how patriarchal relations make a difference to state spatiality and the construction and management of state territory (Jackman et al. 2020). This is particularly important in some policy sectors such as security policy, where women's voices are not only excluded from professional discussions, but also in terms of how key questions around whose security is at stake are negotiated (or neglected) in both war and everyday life (Dowler et al. 2014; Enloe 2000; Fluri 2011; Hörschelmann and Reich 2017).

Feminist scholars destabilize the conceived coherence of the state by inquiring into the 'silenced' voices and discussing, for instance, mundane aspects of security of the private (home), as well as human security-related issues like immigration or labour mobility rather than overly militarized versions of state security (Mullings 2012; Sharp 2007). In sum, one of the political goals of feminist scholarship is to challenge the ongoing militarization and structural violence of states and to develop a politics of security at the intimate scales of the home and body (Koopman 2011). Political geographers working on nationalism and nation building also tend to be critical of the state and the (symbolic) violence wrought by its daily performance, from the mundane to the most elite and global level, though they are often less inclined to define a particular political agenda for their critiques. For decades, this has been a point of anxious discussion among scholars in feminist and critical geopolitics - largely centring around a question of how to imagine a better world outside the oppressive power structures embedded in the statist system (Bachmann and Moisio 2020; Ó Tuathail 2010; Sharp 2000). For some scholars, such as those working in border studies, conflict or settler colonialism, giving voice to the voiceless actors affected by state-controlled decisions is a crucial goal (e.g. Culcasi 2019; Dempsey 2020; Gentry et al. 2019) - a theoretical and methodological impulse that again returns to a feminist ethic of research (Coddington 2017). For others, however, the constructivist lens on the state remains more loosely about understanding basic processes, like why it is that we still take such elusive concepts as the 'state' and the 'nation' for granted (Koch 2015b; Murphy 2013).

\subsubsection{Neoliberalization and the Rescaling of the State}

Although the constructivist approaches arising from human geography's 'cultural turn' in the 1990 s became deeply influential in geographic research on the state, political-economic analyses have remained steadfastly central to disciplinary efforts to retheorize the state. In particular, scholars have accorded a great deal of attention to the neoliberalization of the state, which has proven to be a compelling and impactful set of processes unfolding around the world. In many advanced capitalist states, neoliberalism began in the form of proto-neoliberalism of the 1970s and then manifested itself in the 1980s as the destruction of Keynesian welfarist social and spatial institutions ('roll-back' neoliberalism) and related deregulation. Neoliberalization took an increasingly consolidated form ('roll-out' neoliberalism) in the 1990s through various state restructuring processes and associated modes and reasonings of governance (Peck and 
Tickell 2002). In the frame of historical materialism, neoliberalism is understood as an attempt to restore class power at the global scale (Harvey 2005), while others have approached it as a form of political rationality and form of governing, premised on particular ideational elements and ways of reasoning (Foucault 2007).

As a form of political rationality and discourse, neoliberalism highlights the virtues of free trade, privatization, free markets, proactive statecraft, state downsizing and related public-sector reforms, lean government, austerity measures, flexible labour processes, competitiveness, individualism, entrepreneurialism, policy experiments, innovation and opening up state spaces for the movement of capital and goods. Neoliberalism is a programme of resolving problems of, and developing, human society by means of competitive markets, which are framed as the key to promote economic and organizational efficiency and individual freedom and self-fulfilment. Often accorded a sort of gospel-like prescriptiveness by proponents (such as institutions like the International Monetary Fund or international consulting companies like McKinsey), neoliberal political rationalities spread rapidly around the world from the 1980s onward - especially because they are built on invoking a kind of constant 'crisis' condition or 'state of exception' for the state (Ong 2006). The neoliberal political rationality has thus been deeply influential as a transnational process of policy evolution and learning (Bunnell 2013; Hsu and Hsu 2013). Indeed, neoliberalism could well be the most significant political-ideological rationalization for state restructuring over the three past decades across geographical contexts.

Scholars of neoliberalization have pointed out that it is analytically problematic to treat neoliberalism as an external force or thought virus that exists solely in the sphere of markets. Rather neoliberalization should be conceptualized as a political process of state transformation. The term neoliberalism thus indicates that the state must construct and construe itself in market terms (Brown 2006, p. 694). In neoliberal governmental rationality, the regulation of spatial relations is espoused as the mechanism of competition; the conditions in which the dynamic of competition can exist must be promoted through active state intervention. Neoliberalization thus involves less state intervention to redistribute wealth and more intervention to create markets, support commodification and protect property rights. In neoliberal governmental rationality, 'optimal' political power is thus constituted on the basis of idealized market principles.

Neoliberalization can be equated to the desire to organize social life according to the principles of competition as well as to attempts to encourage enterprising subjectivities, thus resulting in a sort of 'competition state' (Cerny 1990) that is premised on specific geopolitical rationalities (Moisio 2008). The realization of these competitive relations would not have been possible without establishing (transnational) rules and associated performance indicators for interspatial competition, but has largely been reflected in a 'growth-first approach' to urban and regional development. The growth-first approach not only actively supports private interests through the bureaucratic system of the state but also implies a kind of regime of enforcement. This competitive logic has thus gone hand in hand with a wide range of punitive measures for governing people, cities and regions. Overall, the neoliberal logic treats territory, population and state institutions as governable reserves that should be subjected to rational choices grounded in market principles (Ahlqvist and Moisio 2014). The state hence appears as an enterprise association which promotes the commodification of its own activities and structures. The process of commodification also includes privatization and financialization of 
state-owned assets, including public land and the related rise of market players and speculators of land and real estate (Christophers 2018).

Like the commodification of public land, neoliberal logics have been jointly harnessed by those acting 'in the name of the state' and in the 'private' sector to promote extractive industries through land sales, leases and other market-based contracts to exploit the natural resources of a state's territory - or what lays beneath it. This is often articulated through the language of 'resource nationalism' (Koch and Perreault 2019), supposed to enrich a nation by filling state coffers, but these extractivist enterprises are also promoted through the pro-market language of new or reformed states 'joining' the international market economy. This was especially evident in the formerly communist states of Eastern Europe of the Soviet Union as they transitioned to market economies (e.g. Kovács 2015; Quinn 2017; Rogers 2015), but also in other neoliberalizing contexts like Latin America and Africa in the wake of debt crises or regime changes over the last decades (e.g. Andreucci 2017; Emel et al. 2011; Ferguson 2005; Marston 2019).

In addition to targeting natural resources, in some contexts, the neoliberalization of the state has been marked by 'strategic urbanisation' (Moisio and Rossi 2020). In these cases, city-regions and innovative urban spaces emerge as key sites of economic development, spatial planning and the territorial management of the state. State-orchestrated urbanization has become a selective strategy to increase the profitability of capital. The recent proliferation of city-regionalism and start-up urbanism are two examples of state-related 'globalizing' projects that attempt to leverage the infrastructure and human capital of existing urban agglomerations in order to attract investment and create internationally recognized 'hubs' for industry and education. The 'spatial selectivity of the state' (Jones 1997) under neoliberalization can also be understood as partly resulting in often highly economized spatial exceptions such as 'special economic zones' which treat different segments of population differently in terms of rights and privileges (Ong 2006).

All of these neoliberal transformations are encompassed in the 'rescaling of the state' thesis (Brenner 2004), which draws our attention to the spatial changes resulting from and in the formation of the neoliberal state. In Brenner's view, neither what he terms territorial globalization nor deterritorialization are satisfactory: the former simply considers the global scale as a sort of state, but larger, while the latter paradoxically reifies the power of the modern territorial state by heralding its inevitable decline. Rather, the state is best understood as reterritorializing. That is, it is reorganizing the economic and political functions traditionally attributed to the national scale both in terms of rescaling (e.g. strategically devolving regulatory functions to subnational regions and urban agglomerations) and in terms of emphasis (e.g. reducing welfare functions relative to immigration enforcement). These processes have involved new 'competitive' spatial arrangements and transnationalizing state projects that seek to capture global capital flows. Perhaps unsurprisingly, then, the neoliberalization process is marked by a salient spatial privileging: the concentration of particular types of public investments, economic activities and skilled labour in certain privileged city-regions globally and within states. Within this system, cities and city-regions with a higher concentration of activities producing economic value (as measured in hegemonic financial terms) are able to maintain and even strengthen their advantages compared with 'left-behind' regions - themselves pressured into undertaking 'place branding' or other such market-oriented schemes to 'keep up'.

States have nonetheless remained nationalizing projects that aim at both managing societal tensions within state borders and reterritorializing 'global flows' (i.e. managing mobility of 
individuals, goods, ideas and more). Indeed, late neoliberalism is marked by deepening inequalities not only between states, but within states. Recent developments both in Europe and in North America indicate that neoliberalization is producing inequality-related contradictions that make neoliberalism vulnerable in new ways. As a consequence, 'xenophobic populism could well triumph at the ballot box and initiate changes that will destroy the global, hypercapitalist digital economy' (Piketty 2019, p. 2). Uneven geographical development is actually an inherent tendency of contemporary transnational forms of knowledge-intensive capitalism. It may well be one of the emerging contradictions that destabilize the contemporary neoliberalizing knowledge-based economy as a regime of accumulation. Indeed, as part of the recent wave of nativist and populist politics sweeping the world in the last years, neoliberalism has been challenged in new ways - and so too has the state (Brubaker 2020; Jessop 2019; Hart 2019).

\subsection{DIFFICULTIES OF STUDYING THE STATE: SOME NOTES ON METHODOLOGICAL GLOBALISM}

The state remains both an object of analysis and a constituting force within human geography. Over three decades of considering the state as the constellation of forces holding together the political economic arrangements of late modern capitalism, political geographers and geographically minded social scientists have problematized the state, but have also struggled to break free from its conceptual inertia. In the ensuing pages, we consider 'methodological globalism' as one of the challenges that the scholars of the changing geographies of the state may consider when formulating research questions and operationalizing research. As we have already noted, the early geographies of the state understood the state largely as a natural unit of political organization and, in so doing, depoliticized and reified the state as a unit of analysis. This 'methodological nationalism' (see Koch 2020) has been criticized by those who conceptualize the state as socially constructed, contested, contingent and relational - a site and a process rather than a thing.

In the context of this handbook, we refer to 'methodological globalism' as the tendency for social scientists to prioritize the analysis of globalization processes over and above knowledge of the variety of socio-spatial structures, processes and practices that shape state forms and functions at various territorial scales. Many contemporary approaches to economic development, planning and governance take as a pre-given the role of economic globalization as the pre-eminent societal force which moulds, transforms and, increasingly, undermines the state and its constituent national and subnational branches. In some cases, globalization is actively hollowing out the territorial state from above and fostering new subnational and transnational territorial formations - notably, regional industry clusters, global cities, mega-urban regions, etc. These formations, in turn, increasingly contrive to circumnavigate the power and authority of the state. In other approaches, globalization poses an ever present threat to the state's existence as sovereign territorial structure and raises questions about the intellectual efficacy of received understandings of national political citizenship, sovereignty, economy and territorial integrity.

Meanwhile, the state remains a largely invisible spatial category in mainstream urban and regional economic analysis (Storper 2013). Instead, the emphasis in much urban and regional planning and policy is on mapping and measuring the flow of capital, knowledge and information through cities and regions as if these ostensibly global flows operate in a 'borderless 
world' (Ohmae 1995). Despite occasional calls to 'bring the state back' into contemporary spatial analysis (Wissen and Brand 2010), even economic geographers and regional social scientists remain somewhat uncomfortable with the idea that the study of national and subnational state structures and territories offers a stable launch-pad for contemporary critical geo-economic and geopolitical analyses.

From a critical realist perspective, methodological globalism can be regarded as containing a set of ontological assumptions in which causal powers are pre-assigned to various global political and economic actors and institutions somehow operating 'above', or apart from, the state. Such powers - and the corresponding liabilities - derive first and foremost from the putative global reach and influence of various non-state actors rather than from any material attachment to places, regions and territories - for example, a stake in the fiscal capacities of local or metropolitan government jurisdictions (Cox and Jonas 1993). These actors, it seems, have the capacity to exercise their powers unmediated by those of state actors. At best, the state is treated as a contingent effect, or by-product, of societal processes which are conceived of as essentially non-territorial or (in current terminology) relational. Whereas the state was once the very essence of territoriality, much of social theory today is constructed around relational processes and their non-state-centric effects and outcomes.

Nonetheless, there may be ways of (re)positioning the territorial state within these ostensibly relational narratives; ways which are implicit in extant state-theoretical approaches. For example, in world systems approaches states are treated as pre-given territorial structures that operate within, and respond to, the global system of exchange in a quasi-autonomous fashion. Likewise, in regulation theory, subnational state competitiveness reflects how the national state itself has responded to wider political and economic trends, such as the rise of neoliberalism, by rescaling its internal powers and capacities (Brenner 2004). Even in actor-network theory, collective action inside the state is not simply an effect of relational processes; it often depends upon how political actors assemble wider infrastructural resources within territories (e.g. cities and regions) that nevertheless possess fixed political boundaries and often limited fiscal capacities (Sassen 2013). Such varied perspectives on the role of the state and its constituent political actors, networks and spaces ultimately hint at the near impossibility of separating knowledge of the essential territoriality of the state from relational understandings of globalization and societal change.

Nevertheless, the recent ascendancy of methodological globalism is perhaps understandable given that state theory had reached something of an impasse by the end of the twentieth century. At that time, Marxist state theorists in particular had been locked into quite intractable debates, not the least of which was the question of the relative autonomy of the state from the capital-labour relation (see e.g. Poulantzas 1978; Jessop 1990). When judged by today's standards, state theory could not be accused of overly territorial thinking at the time; yet it seemed to some that the only way of overcoming this theoretical impasse was to de-essentialize knowledge of the capital-labour relation. As Kennedy (2006, p. 182) has argued, 'the state has a capacity for relative autonomy premised on the negation of capitalism and, therefore, the negation of the basis of capitalist ruling class's rule over the form of labour extraction ... the social space for the state's relative autonomy emerges on the basis of the suppression of the categories of capital and labour'. However, many others - especially political geographers - have since argued that it is necessary to think of capitalist relations of production not so much in an abstract sense as being devoid of any necessary spatial content but instead to show how space and territory (at least in a more general sense) make a fundamental difference to 
the manner in which capital and labour are materially and socially constituted. Cox (2002), for example, argues that capital requires the production of certain spatial forms (e.g. land, buildings, infrastructure, housing, etc.) in order to accumulate. By the same token, it can be argued that the state requires certain territorial forms - e.g. local fiscal arrangements, regional land use plans, local electoral districts, etc. - in order to facilitate accumulation and political participation.

In his early forays into state theory, Lefebvre had already proposed a potential solution to the challenges of essentialism (a.k.a. methodological globalism) by drawing a distinction between capitalism's mondialité, which roughly means the 'worldness' or general character of its underlying social relations, and mondial, which in this context refers to capitalism's 'worldwide' reach - i.e. its expansion on a planetary scale (Lefebvre 1976). Lefebvre emphasized that globalization is not pre-given but evolves and morphs spatially in response to various tensions and contradictions expressed at urban, national and international scales. In economic geography, there have been similar calls to de-essentialize knowledge of global capitalism and class relations by exploring the diverse concrete economic forms and practices that operate and exist within and between localities and regions (Gibson-Graham 2006). Given all of this, the intellectual challenge to state theory posed by methodological globalism results not so much from its ignorance of the various territorial structures and properties of the state - in fact, a vast corpus of state theory has scant regard for the geography of the state - but rather its failure to address the relationship between capitalism's diverse spaces of globalization (Cox 1997) and the state's ever fluctuating internal and external geographies. One potential solution to the problem of territorial non-coincidence (Murray 1971) and its geographical equivalent, the 'territorial trap' (Agnew 1994), considers how the state is positioned vis-à-vis extra-territorial threats, such as globalization, by adjusting its geopolitical configuration. However, such geopolitical analysis itself confronts an equivalent challenge of essentializing the causal importance of state territory at the expense of knowledge of non-state spatial formations and flows. For instance, traditional understandings of geopolitics often took the territorial state and its borders as fixed or pre-given spatial entities from which political power and control emanate outwards into the wider world of international relations. Accordingly, a state's geopolitical influence could be measured against its 'mastery' of (state) territory within and especially beyond its (national) borders.

However, critical geopolitical scholars, including Agnew and Corbridge (1995), challenge this traditional viewpoint by addressing a government's desire to control not just a state's territory but also spatial flows of money, capital, knowledge and material resources. Out of this a more critical understanding of geopolitics has emerged, whereby the international competitiveness (or resilience) of the modern state is secured not so much by the control of state territory and borders as by the state's capacity to mobilize and harness flows of capital and knowledge around new spatial formations, including cities, city-regions and especially mega-urban regions (which might themselves transcend national borders). As Moisio (2018a, p. 4) argues: 'the preceding state-centered era epitomized by the term geopolitics has been replaced by the notion of the international competitiveness of the state based on generating competitive advantages (of nations) through different kinds of spatial formations as well as new kinds of citizen subjectivities'. This leads to the insight that a state's ability to corral global flows both within and beyond its borders can serve as an instrument of exerting international influence, which is mobilized by ruling national elites to reassert the geopolitical authority and territorial integrity of the state notwithstanding the 'hollowing-out' effects of globalization. 
Finally, it is worth noting that the incorporation of non-essentialist renditions of territory into state theory is not without its challenges. Here we highlight two potential issues. The first relates to the question of national territory. The second relates to the question of scale. With regard to the first, there is the question of how to investigate the state's internal and extra-territorial powers, structures and processes without essentializing their 'national' territorial origins and reach. The functional approaches in political geography, as discussed above, tended to separate out the state's internal and external functions. That is, they attributed the organization of the state's internal territorial structures to countervailing forces of national integration/fragmentation, on the one hand, and its external relations with other states and economies to wider geopolitical factors, on the other. Instead, we need to consider how the state simultaneously projects both internally and externally often quite different material and discursive representations of national territory as it engages with processes of economic globalization and various social, environmental and distributional problems (Jonas and Moisio 2018). For example, how and why did the idea of a 'national economy' emerge under Keynesianism (see Radice 1984) and what geopolitical myths and imaginaries have in the meantime replaced this particular representation of national territory? Challenging methodological globalism involves rethinking the geography of the state not in terms of an internal versus external duality but how the very essence and idea of the 'national' is mobilized through all sorts of geopolitical practices and imaginaries.

The second issue concerns what Lefebvre (1976) referred to as the 'politics of space' how the state manages national and urban spatial structures to accommodate the worldwide expansion of capitalism - but today would be more commonly described as the 'politics of scale'. For contemporary state theorists, the language of scale is often interchangeable with that of territory (Jessop et al. 2008), especially when it comes to undertaking a serious analysis of the state, its changing structures, functions and capacities, and its evolving relationship to the global landscape of accumulation. Scale-sensitive state theory immeasurably helps to shed light on how state territory adjusts to changes in capital's accumulation strategies and, crucially, vice versa. In contrast to a methodological globalism that essentializes the causality of the global scale, we would always advocate a scalar method or ontology that does not pre-assign causality to any specific territorial scale either within or without the state - such considerations are instead questions requiring further empirical investigation rather than matters demanding strident and uncritical a priori assertion.

\subsection{THE FUTURE: NEW SPACES OF GEOPOLITICS}

We conclude this chapter with introducing eight themes that we believe merit attention in taking the geographical analysis of the state further. First, Indigenous geographies need to be foregrounded in future scholarship on the state. As Velednitsky et al. (2020) have recently noted, the most significant 'present absence' in political geography today is a serious engagement with settler colonial theory. Until now, there have only been modest efforts to integrate into mainstream discussions of state theory the vast and crucial research in Indigenous studies scholarship on sovereignty, state power, settler colonialism and modes of relating to the land within and beyond the territorial state (e.g. Bonds and Inwood 2015; Busbridge 2020; Curley 2019; Grydehøj and Ou 2017; Naylor et al. 2018; Nicol 2017; Norman 2014). As this work shows, the contemporary state cannot be understood outside of colonialism - but that coloni- 
alism is not just a past, but a present. A key challenge for future scholarship on the state is to understand the ongoing renewal and/or contestation of Indigenous forms of self-determination within settler colonial states. Doing so, Michelle Daigle (2016, p. 261) suggests, demands a close study of everyday geographies and the 'lived practices of Indigenous self-determination', but that this need not mask how these practices are 'nested' within and a part of 'the sovereignty of the settler colonial state and capitalist structures of accumulation'. Rather, as discussed throughout this chapter, these broader structural forces cannot be understood without the grounded perspective of the everyday, and vice versa. Indigenous geographies are political geographies, so understanding the spatial and conceptual shifts of the state requires listening to and raising these perspectives.

Second, we are witnessing a particular 'ecologization of politics' that demands sustained academic attention. This is a process whereby the state is also spatially transformed, as individuals, institutions and other political structures are called upon to adopt and internalize a particular logics of environmental 'sustainability' (Whitehead et al. 2007). This kind of 'sustainability state' nonetheless remains largely a capitalist state, which is now being tailored to counteract the crisis tendencies of late capitalism which emanate from global climate change (Ioris 2015). Indeed, many of the material and policy shifts seen under the banner of the 'ecologization of politics' in recent years actually do little to improve environmental problems, and instead reinforce state institutions' hegemony and their relation with private interests - albeit in innovative ways and through 'eco-friendly' rhetoric. This is particularly problematic in certain authoritarian states and institutions, as well as sites targeted by extractive industries (e.g. Belcher et al. 2020; Curley 2018; Koch 2018a; Marston 2019; McCreary and Milligan 2014; Zhou 2015). In other contexts, however, some political leaders and citizens have drawn upon the ideals of social justice to advocate for 'just transitions', i.e. the reorganization of human activities within particular 'environmental limits' while ensuring that the policies introduced are societally legitimate and fair (Jasanoff 2018; Routledge et al. 2018). When advanced around an 'eco-welfare-state' ideal, these changes may facilitate a transition towards the next phase of knowledge-intensive capitalism (Moisio and Rossi 2020), or some as yet unknown form of 'eco-state restructuring' (While et al. 2010). Whatever the case may be, the ecologization of politics and its relationship with state spatial transformation is a theme that merits rigorous research in the future, whether under the rubric of political geography, political ecology, environmental geopolitics or some critical environmental combination of all (Dalby 2020; Death 2014; Loftus 2020; O’Lear 2020).

Third, there is a need to continue theorizing the local state in late neoliberalism. It is pertinent to examine how the transformation of cities and states is a co-constituted process, and how the 'national' is being built into the local state in different geographical contexts and in various political projects dealing with issues such as housing, economic development and policing urban space in the name of 'security' (Coleman 2009; Kaufman 2016). In other words, the state often plays a role in transforming cities during the age of neoliberalism, but these state-orchestrated projects often occur in extra-local relations beyond the localities so impacted. This kind of national-state orchestrated politics of the local state manifests itself in projects that bring together the national state apparatus, transnational actors that seek to financialize the urban environment and consultancies that mobilize transnational circuits of knowledge. The relationship between the local state, the national state and circuits of financialization is thus a topic that merits rigorous geographical research. 
Regarding what we argue above, local and national spatial development and planning policies offer an interesting entry point into the ways in which the local state, national state and transnational finance come together in the age of late neoliberalism. The rise of the 'intangible economies' and rapid urbanization have initiated a large-scale revaluing of national real estate assets - land, buildings, infrastructures, natural resources, etc. - and the redistribution of the rights to extract them. The economic consequences of such revaluing and redistribution have been remarkably different. In growing urban areas the real estate industry has expanded significantly (Stein 2019) while in the declining periphera and deindustrializing regions real estate values have decreased dramatically. Both of these contexts have nonetheless faced similar consequences: the growing influence and interest of transnational finance in planning and development policies. In urban centres, planners and developers are increasingly involved in cooperative development projects with transnational real estate investors and business angels who seek to benefit from inflated real estate prices (e.g. Hyötyläinen and Haila 2018). In the declining regions and localities in turn, lower prices and decreasing real estate values also attract investors and speculators. In both spatial contexts, planners and developers seek to produce value through planning and developing milieux which attract investments. Harvey (1973) noted some five decades ago that planning is a political activity in the service of capital and capitalist state. In the same spirit, we argue that the ongoing valorization of urban and peripheral spaces by public authorities, large-scale revaluing of national real estate assets under late neoliberalisation and the increasing influence of transnational actors in local and national planning policies deserve rigorous scholarly attention.

Fourth, there is a need to continue investigating the role of the state in the process of contemporary knowledge-based economization and its qualitative shifts. The privatization of governance, the processes of datafication and digitalization all merit close scholarly scrutiny - particularly under new regimes of 'surveillance capitalism' (Zuboff 2019). This form of knowledge-based economization is built on a kind of 'epistemic inequality', whereby a fast-growing cleavage is now appearing between what we know and what is known about us. As sources of potential insecurity proliferate across biological, technological and climate realms, constellations of states and non-state actors will construct problems and solutions that seek to render these as legible subjects of the state security apparatus. While the state has a major role to play in these securitizing processes, the private sector is becoming increasingly prominent in shaping threat definition and response by supplying, and in some cases controlling access to, infrastructure and resources. Drawing on new tools of digitalization and datafication, surveillance capitalism operates through technologies such as facial recognition and other privatized technologies, while also uniting corporate and state power in new combinations (Glasius and Michaelsen 2018). State-orchestrated efforts to reterritorialize the state at the age of digitalization and datafication remain important topics in the study of state transformation - vividly illustrated by the COVID-19 crisis unfolding across the world at the time of writing. State health agencies are, in some cases, relying on private-sector clinics or testing facilities to bolster their capacity - illustrating how the state's incomplete grasp in this area of 'security' provision cannot be understood as the sole purview of the state, even where such claims are made.

Fifth, the transformation of the state as a geopolitical persona remains an important research topic in geographical studies of the state. It is highly likely that the social organization called the state will not exist, say, in the year 2500, or that it will exist in a fundamentally altered form. It would be important to examine various geopolitical utopias in the present, utopias that 
either portray new kinds of statehood or seek to build new kinds of political communities as alternatives to the contemporary state. As Frederic Jameson (2004, p. 44) has argued, narrating a kind of utopia involves constructing a discursive realm in which 'political institutions seem both unchangeable and infinitely modifiable', and are thus transformed in 'the object and raw material of ceaseless mental play'. Some urban utopias, for example, might thus reveal how the logics and techniques of territorial governance could be reimagined. These range from 'green utopias' (Garforth 2017) to globalizing city imaginaries whereby the global city network and 'great cities' are represented as if they were more 'functional' political communities than 'dysfunctional' Others (Datta and Shaban 2016; Pinder 2005). Utopian narratives thus call our attention to deep social and political divides of who gets to imagine and share their vision of an ideal future. It is thus essential that future research on the shifting geographies of the state attend to the fact that for many actors, the celebratory discourses of utopia - and the dystopian discourses of environmental catastrophe motiving projects of 'eco-state restructuring' - overlook what Curley and Lister (this volume) refer to as the 'already existing dystopias' common to so many Indigenous peoples. As they and other Indigenous scholars have argued, the settler state is an already existing dystopia, as these groups have had their lands and territorial regimes subjected to world-changing catastrophes for centuries - but they nonetheless continue to be written out of visions for a 'green' or otherwise-defined utopian future (Barker 2005; Blackhawk 2006; Daigle 2016; Nicol 2017; Whyte 2018).

Sixth, the events of the end of the second decade of the twenty-first century show that even in cases where state functions have proven to be weak or unreliable, the 'allure' (Murphy 2013) of the territorial state is as stronger as ever. What is perhaps most surprising is that the desire for a stronger, more authoritarian state is coming in some cases from electoral majorities and pluralities. Across Europe and North America, voters are choosing parties and leaders that promise an end to partisan gridlock and a solution to the excesses of globalization - if only they will support draconian policies to exclude newcomers and renew an idealized national culture (Brubaker 2020; Lizotte 2019). We should also be attuned to situations in which non-state actors attempt to ape state mechanisms for reproducing its territory and enforce a politics of exclusion. Vigilante territorial policing is one form of this, found in settings such as the United States (Williams and Boyce 2013), Bulgaria (Krasteva 2017) or Lebanon (Sanyal 2018). Such acts depend on existing mechanisms and technologies of state territory, but take their exclusionary potential to a logical extreme. We should also inquire into attempts to remake state territoriality while retaining the basic conventions of state territoriality. More traditional kinds of authoritarian politics have not gone away, however, so it remains important to understand how actors in these states have reacted to open borders and footloose capital by reaffirming territorial control - not just over physical but also psychic national space, in addition to trying to capture capital themselves through all range of 'spectacular' developments (Koch 2018b). These developments merit careful scholarly attention if we are to understand how governments secure support for state power in a concrete way, and how it is made coherent and present to the everyday lives of political subjects.

Seventh, we invite further scholarship on state-city relations. We suggested above that the consolidation of global neoliberal capitalism has led to a significant reterritorialization of the state around all sorts of new and ostensibly competitive urban spatial forms (e.g. global city-regions, rescaled modes of urban governance, etc.) along with transnational state projects that seek to capture global capital flows. At the same time, states have pursued often overtly national(ist) projects of territorial redistribution and social control, which strive to manage 
growing societal tensions and inequalities within national state borders. This is seen, for example, in the way that certain authoritarian states across Asia, from Qatar to Myanmar to Kazakhstan, ruling elites have built spectacular capital cities to secure a degree of loyalty from their populations - while also monopolizing the right to act in the name of the 'state' that allows them to exploit resource wealth for themselves (Koch 2016, 2018b). In these places and elsewhere, politicians and managers engage in various forms of urban diplomacy that enable cities to reach out far beyond national borders and access global flows of information, capital, resources and policy knowledge (Phelps and Miao 2020). To the extent that such internationalization agendas of states are aligning with those of cities, city-regions and mega-urban regions, it raises questions about how various urbanization strategies are used as geopolitical instruments for states and other actors working within capitalist circuit networks, supranational organizations and beyond.

Finally, scholars need analytical skills to think beyond the state. This requires not only an empirical assessment of state functions but also a critical recognition and examination of what Jessop (2016) calls the state idea. There is broad agreement that what we understand as the state is a constellation of forces held in fragile relationships with one another through historically and geographically specific circumstances that must reproduce itself ideologically if it is to endure territorially (Herb 2004). The intention of these social forces - the state idea - has been to 'establish, exercise, and consolidate political power over the population of a specific territory (Jessop 2016, p. 19). Herein lies somewhat of a conundrum, as recognizing the contingency of the state, for most scholars, is accompanied by the twin recognition that this contingency has proven to be remarkably firm and infirm over time and across space. But as our Indigenous colleagues have long argued, other sovereignties are possible (Daigle 2016). The 'settler cartographies' of the state should never be taken for granted, so the question for us is how to think beyond the state, without reproducing the colonial erasures that it is built upon, for 'when we engage in dialogic narratives through counterfactual space, we can connect ourselves to the errors of our ancestors and work to change how we do things today so as to learn needed lessons to pass on to future generations' (Whyte 2018, p. 238).

\section{REFERENCES}

Abrams, P. (1977/1988), 'Notes on the difficulty of studying the state', Journal of Historical Sociology, 1, 58-89.

Agnew, J.A. (1994), 'The territorial trap: The geographical assumptions of international relations theory', Review of International Political Economy, 1, 53-80.

Agnew, J.A. (2002), Making Political Geography, London: Arnold.

Agnew, J.A. (2005), 'Sovereignty regimes: Territoriality and state authority in contemporary world politics', Annals of the Association of American Geographers, 95 (2), 437-61.

Agnew J.A. and S. Corbridge (1995), Mastering Space: Hegemony, Territory and International Political Economy, London: Routledge.

Ahlqvist, T. and S. Moisio (2014), 'Neoliberalization in a Nordic state: From cartel polity towards a corporate polity in Finland', New Political Economy, 19 (1), 21-55.

Anderson, B. (1983), Imagined Communities: Reflections on the Origin and Spread of Nationalism, London: Verso.

Andreucci, D. (2017), 'Resources, regulation and the state: Struggles over gas extraction and passive revolution in Evo Morales's Bolivia', Political Geography, 61, 170-80.

Bachmann, V. and S. Moisio (2020), 'Towards a constructive critical geopolitics: Inspirations from the Frankfurt School of critical theory', Environment and Planning C: Politics and Space, 38 (2), 251-68. 
Ballvé, T. (2012), 'Everyday state formation: Territory, decentralization, and the narco landgrab in Colombia', Environment and Planning D: Society and Space, 30 (4), 603-22.

Barber, B. (2013), If Mayors Ruled the World: Dysfunctional Nations, Rising Cities, New Haven, CT: Yale University Press.

Barker, J. (2005), Sovereignty Matters: Locations of Contestation and Possibility in Indigenous Struggles for Self-Determination, Lincoln, NE: University of Nebraska Press.

Belcher, O., P. Bigger, B. Neimark and C. Kennelly (2020), 'Hidden carbon costs of the "everywhere war": Logistics, geopolitical ecology, and the carbon boot-print of the US military', Transactions of the Institute of British Geographers, 45 (1), 65-80.

Benwell, M.C., A. Núñez and C. Amigo (2019), 'Flagging the nations: Citizens' active engagements with everyday nationalism in Patagonia, Chile', Area, 51 (4), 719-27.

Bernazzoli, R. and C. Flint (2010), 'Embodying the garrison state? Everyday geographies of militarization in American society', Political Geography, 29 (3), 157-66.

Billig, M. (1995), Banal Nationalism, Thousand Oaks, CA: Sage.

Blackhawk, N. (2006), Violence over the Land: Indians and Empires in the Early American West, Cambridge, MA: Harvard University Press.

Block, F. (1987), Revising State Theory, Philadelphia, PA: Temple University Press.

Bonds, A. and J. Inwood (2015), 'Beyond white privilege: Geographies of white supremacy and settler colonialism', Progress in Human Geography, 40 (6), 715-33.

Bourdieu, P. (1999), 'Rethinking the state: Genesis and structure of the bureaucratic field', in G. Steinmetz (ed.), State/Culture: State-Formation after the Cultural Turn, Ithaca, NY: Cornell University Press, pp. 53-75.

Brenner, N. (2004), New State Spaces: Urban Governance and the Rescaling of Statehood, New York: Oxford University Press.

Brown, W. (2006), 'American nightmare: Neoliberalism, neoconservatism, and dedemocratization', Political Theory, 34, 690-714.

Brubaker, R. (2020), 'Populism and nationalism', Nations and Nationalism, 26 (1), 44-66.

Bunnell, T. (2013), 'Antecedent cities and inter-referencing effects: Learning from and extending beyond critiques of neoliberalisation', Urban Studies, 52 (11), 1983-2000.

Busbridge, R. (2020), 'Messianic time, settler colonial technology and the elision of Palestinian presence in Jerusalem's historic basin', Political Geography, 79, 102-58.

Butler, J. (1990), Gender Trouble: Feminism and the Subversion of Identity, New York: Routledge.

Cerny, P. (1990), The Changing Architecture of Politics, London: Sage.

Chouinard, V. (2004), 'Making feminist sense of the state and citizenship', in L. Staeheli, E. Kofman and L. Peake (eds), Mapping Women, Making Politics: Feminist Perspectives of Political Geography, New York: Routledge, pp. 227-45.

Christophers, B. (2018), The New Enclosure: The Appropriation of Public Land in Neoliberal Britain, New York: Verso.

Clark, G.L. and M. Dear (1984), State Apparatus, Boston: Allen and Unwin.

Coddington, K. (2017), 'Voice under scrutiny: Feminist methods, anticolonial responses, and new methodological tools', The Professional Geographer, 69 (2), 314-20.

Coleman, M. (2009), 'What counts as the politics and practice of security, and where? Devolution and immigrant insecurity after 9/11', Annals of the Association of American Geographers, 99 (5), 904-13.

Cox, K.R. (ed.) (1997), Spaces of Globalization: Reasserting the Power of the Local, New York: Guilford Press.

Cox, K.R. (2002), Political Geography: Territory, State and Society, Oxford: Blackwell.

Cox, K.R. and A.E.G. Jonas (1993), 'Urban development, collective consumption and the politics of metropolitan fragmentation', Political Geography, 12, 8-37.

Culcasi, K. (2019), "We are women and men now": Intimate spaces and coping labour for Syrian women refugees in Jordan', Transactions of the Institute of British Geographers, 44 (3), 463-78.

Curley, A. (2018), 'A failed green future: Navajo green jobs and energy "transition" in the Navajo Nation', Geoforum, 88, 57-65.

Curley, A. (2019), “'Our Winters' rights”: Challenging colonial water laws', Global Environmental Politics, 19 (3), 57-76. 
Daigle, M. (2016), ‘Awawanenitakik: The spatial politics of recognition and relational geographies of Indigenous self-determination', Canadian Geographer/Le Géographe Canadien, 60 (2), 259-69.

Dalby, S. (2020), Anthropocene Geopolitics: Globalization, Security, Sustainability, Ottawa: University of Ottawa Press.

Datta, A. and A. Shaban (2016), Mega-Urbanization in the Global South: Fast Cities and New Urban Utopias of the Postcolonial State, New York: Routledge.

Death, C. (2014), Critical Environmental Politics, New York: Routledge.

Dempsey, K. (2020), 'Spaces of violence: A typology of the political geography of violence against migrants seeking asylum in the EU', Political Geography, 79, 102-57.

Dittmer, J. (2005), 'Captain America's empire: Reflections on identity, popular culture, and post-9/11 geopolitics', Annals of the Association of American Geographers, 95 (3), 626-43.

Dittmer, J. and D. Bos (2019), Popular Culture, Geopolitics, and Identity, Lanham: Rowman and Littlefield.

Dixon, D. (2015), Feminist Geopolitics: Material States, Farnham: Ashgate Publishing.

Dixon, D. and S. Marston (2011), 'Introduction: Feminist engagements with geopolitics', Gender, Place and Culture, 18 (4), 445-53.

Dowler, L. and J. Sharp (2001), 'A feminist geopolitics?' Space \& Polity, 5 (3), 165-76.

Dowler, L., J. Christian and A. Ranjbar (2014), 'A feminist visualisation of the intimate spaces of security', Area, 46 (4), 347-9.

Edensor, T. (2002), National Identity, Popular Culture and Everyday Life, New York: Berg.

Emel, J., M. Huber and M. Makene (2011), 'Extracting sovereignty: Capital, territory, and gold mining in Tanzania', Political Geography, 30 (2), 70-9.

Enloe, C. (1988), Does Khaki Become You? The Militarization of Women's Lives, London: Pandora.

Enloe, C. (2000), Bananas, Beaches and Bases: Making Feminist Sense of International Politics, Berkeley, CA: University of California Press.

Falah, G.-W., C. Flint and V. Mamadouh (2006), 'Just war and extraterritoriality: The popular geopolitics of the United States' war on Iraq as reflected in newspapers of the Arab world', Annals of the Association of American Geographers, 96 (1), 142-64.

Ferguson, J. (2005), 'Seeing like an oil company: Space, security, and global capital in neoliberal Africa', American Anthropologist, 107 (3), 377-82.

Fluri, J. (2011), 'Bodies, bombs and barricades: Geographies of conflict and civilian (in)security', Transactions of the Institute of British Geographers, 36 (2), 280-96.

Foucault, M. (2007), Security, Territory, Population. Lectures at the Collège de France, 1977-78, London: Palgrave Macmillan.

Funnell, L. and K. Dodds (2017), Geographies, Genders and Geopolitics of James Bond, London: Palgrave Macmillan.

Garforth, L. (2017), Green Utopias: Environmental Hope before and after Nature, Malden, MA: Polity.

Gentry, B., G. Boyce, J. Garcia and S. Chambers (2019), 'Indigenous survival and settler colonial dispossession on the Mexican frontier: The case of Cedagi Wahia and Wo'oson O'odham Indigenous communities', Journal of Latin American Geography, 18 (1), 65-93.

Gibson-Graham, J.K. (2006), A Postcapitalist Politics, Minneapolis, MN: University of Minnesota Press.

Glasius, M. and M. Michaelsen (2018), 'Illiberal and authoritarian practices in the digital sphere: Prologue', International Journal of Communication, 12, 3795-813.

Gordon, C. (1991), 'Governmental rationality: An introduction', in G. Burchell, C. Gordon and P. Miller (eds), The Foucault Effect: Studies in Governmentality, Chicago, IL: University of Chicago Press, pp. 1-51.

Gottmann, J. (1951), ‘Geography and international relations’, World Politics, 3, 153-73.

Gottmann, J. (1952), 'The political partitioning of our world: An attempt at analysis', World Politics, 4, 512-19.

Gottmann, J. (1961), Megalopolis, New York: 20th Century Fund.

Grydehøj, A. and Z. Ou (2017), 'Deterritorialization of indigeneity: Indigenous territory, development policy, and the Dan fishing community of Hainan (China)', Political Geography, 61, 77-87.

Hannah, M. (2000). Governmentality and the Mastery of Territory in Nineteenth-Century America, Cambridge: Cambridge University Press. 
Hannah, M. (2009), 'Calculable territory and the West German census boycott movements of the 1980s', Political Geography, 28 (1), 66-75.

Hart, G. (2019), 'From authoritarian to left populism?: Reframing debates', South Atlantic Quarterly, 118 (2), 307-23.

Hartshorne R. (1950), 'The functional approach in political geography', Annals of the Association of American Geographers, 40, 95-130.

Harvey, D. (1973), Social Justice and the City, London: Edward Arnold.

Harvey D. (1985), 'The geopolitics of capitalism', in D. Gregory and J. Urry (eds), Social Relations and Spatial Structures: Critical Human Geography, London: Palgrave, pp. 128-63.

Harvey, D. (1989), 'From managerialism to entrepreneurialism: The transformation in urban governance in late capitalism', Geografiska Annaler B: Human Geography, 71, 3-17.

Harvey, D. (1990), The Condition of Postmodernity, Oxford: Blackwell.

Harvey, D. (2005), A Brief History of Neoliberalism, Oxford: Oxford University Press.

Heffernan, M. (2000), 'Fin de siècle, fin du monde? On the origins of European geopolitics', in K. Dodds and D. Atkinson (eds), Geopolitical Traditions: A Century of Geopolitical Thought, London: Routledge, pp. 27-51.

Herb, G. (2004), 'Double vision: Territorial strategies in the construction of national identities in Germany, 1949-1979', Annals of the American Association of Geographers, 94 (1), 140-64.

Holland, E. and A. Levy (2018), 'The Onion and the geopolitics of satire', Popular Communication, 16 (3), 182-95.

Hörschelmann, K. and E. Reich (2017), 'Entangled (in)securities: Sketching the scope of geosocial approaches for understanding "webs of (in)security", Geopolitics, 22 (1), 73-90.

Hsu, J. and Y. Hsu (2013), 'State transformation, policy learning, and exclusive displacement in the process of urban redevelopment in Taiwan', Urban Geography, 34 (5), 677-98.

Hull, M. (2012), Government of Paper: The Materiality of Bureaucracy in Urban Pakistan, Berkeley, CA: University of California Press.

Hyötyläinen, M. and A. Haila (2018), 'Entrepreneurial public real estate policy: The case of Eiranranta, Helsinki', Geoforum, 89, 137-44.

Ince, A. and G. Barrera de la Torre (2016), 'For post-statist geographies', Political Geography, 55, $10-19$.

Ioris, A. (2015), 'Theorizing state-environment relationships: Antinomies of flexibility and legitimacy', Progress in Human Geography, 39 (2), 167-84.

Jackman, A., R. Squire, J. Bruun and P. Thornton (2020), 'Unearthing feminist territories and terrains', Political Geography, 80, 102-80.

Jameson, F. (2004), 'The politics of utopia', New Left Review, 25, 35-54.

Jasanoff, S. (2018), 'Just transitions: A humble approach to global energy futures', Energy Research and Social Science, 35, 11-14.

Jessop, B. (1990), State Theory: Putting the Capitalist State in its Place, Cambridge: Cambridge University Press.

Jessop, B. (1992), 'Fordism and post-Fordism: A critical reformulation', in A.J. Scott and M. Storper (eds), Pathways to Regionalism and Industrial Development, London: Routledge, pp. 43-65.

Jessop, B. (2008), State Power, Cambridge: Polity Press.

Jessop, B. (2016), The State: Past, Present, Future, Cambridge: Polity.

Jessop, B. (2019), 'Authoritarian neoliberalism: Periodization and critique', South Atlantic Quarterly, 118 (2), 343-61.

Jessop, B. and N.-L. Sum (2006), Beyond the Regulation Approach, Cheltenham, UK and Northampton, MA, USA: Edward Elgar Publishing.

Jessop B., N. Brenner and M. Jones (2008), 'Theorizing sociospatial relations', Environment and Planning D: Society and Space, 26, 389-401.

Johnston, R.J. (1992), Geography and the State, New York: St Martin's Press.

Jonas, A.E.G. (2013), 'City-regionalism as contingent "geopolitics of capitalism”, Geopolitics, 18, 284-98.

Jonas A.E.G. and S. Moisio (2018), 'City regionalism as geopolitical processes: A new framework for analysis', Progress in Human Geography, 42, 350-70. 
Jones, M. (1997), 'Spatial selectivity of the state? The regulationist enigma and local struggles over economic governance', Environment and Planning A, 29, 831-64.

Jones, R. (2007), People/States/Territories: The Political Geographies of British State Transformation, Oxford: Blackwell.

Jones, R. (2014), 'Border Wars: Narratives and images of the US-Mexican border on TV', ACME: An International Journal for Critical Geographies, 13 (3), 530-50.

Jones, R. and P. Merriman (2009), 'Hot, banal and everyday nationalism: Bilingual road signs in Wales', Political Geography, 28 (3), 164-73.

Kaufman, E. (2016), 'Policing mobilities through bio-spatial profiling in New York City', Political Geography, 55, 72-81.

Kennedy P. (2006), 'Marxism and the relative autonomy of the capitalist state', Critique: Journal of Socialist Theory, 34, 179-96.

Khanna, P. (2016), Connectography: Mapping the Future of Global Civilization, New York: Random House.

Kivelä, S. (2018), 'Constructing the territorial state through the mundane: Statization of everyday population health', Geografiska Annaler B: Human Geography, 100, 25-41.

Koch, N. (2013), 'Sport and soft authoritarian nation-building', Political Geography, 32, 42-51.

Koch, N. (2015a), 'Gulf nationalism and the geopolitics of constructing falconry as a "heritage sport"', Studies in Ethnicity and Nationalism, 15 (3), 522-39.

Koch, N. (2015b), “'Spatial socialization”: Understanding the state effect geographically', Nordia Geographical Publications, 44 (4), 29-35.

Koch, N. (2016), 'Is nationalism just for nationals? Civic nationalism for noncitizens and celebrating National Day in Qatar and the UAE', Political Geography, 54 (1), 43-53.

Koch, N. (2018a), "Green laboratories: University campuses as sustainability "exemplars" in the Arabian Peninsula', Society and Natural Resources, 31 (5), 525-40.

Koch, N. (2018b), The Geopolitics of Spectacle: Space, Synecdoche, and the New Capitals of Asia, Ithaca, NY: Cornell University Press.

Koch, N. (2020), 'Nationalism, methodological', in A. Kobayashi (ed.), The International Encyclopedia of Human Geography (2nd ed., Vol. 9), Oxford: Elsevier, pp. 245-8.

Koch, N. and A. Paasi (2016), 'Banal Nationalism 20 years on: Re-thinking, re-formulating and re-contextualizing the concept', Political Geography, 54, 1-6.

Koch, N. and T. Perreault (2019), 'Resource nationalism', Progress in Human Geography, 43 (4), 611-31.

Koopman, S. (2011), 'Alter-geopolitics: Other securities are happening', Geoforum, 42 (3), 274-84.

Kovács, E. (2015), 'Surveillance and state-making through EU agricultural policy in Hungary', Geoforum, 64, 168-81.

Krasteva, A. (2017), 'If borders did not exist, Euroskepticism would have invented them or, on post-Communist re/de/re/bordering in Bulgaria', Geopolitics, doi.org/10.1080/14650045.2017 .1398142

Kuus, M. (2015), 'Transnational bureaucracies: How do we know what they know?', Progress in Human Geography, 39 (4), 432-48.

Lauria, M. (ed.) (1997), Reconstructing Urban Regime Theory: Regulating Urban Politics in a Global Economy, Thousand Oaks, CA: Sage.

Lefebvre H. (1976), De L'Etat, Paris: Union Général d'Éditions.

Lemke, T. (2007), 'An indigestible meal? Foucault, governmentality and state theory', Distinktion: Scandinavian Journal of Social Theory, 8 (2), 43-64.

Lizotte, C. (2019), 'Where are the people? Refocusing political geography on populism', Political Geography, 71, 139-41.

Loftus, A. (2020), 'Political ecology II: Whither the state?', Progress in Human Geography, 44 (1), $139-49$.

Luukkonen, J. and H. Sirviö (2019), 'The politics of depoliticization and the constitution of city-regionalism as a dominant spatial-political imaginary in Finland', Political Geography, 73, 17-27.

MacKinnon, C. (1989), Toward a Feminist Theory of the State, Cambridge, MA: Harvard University Press. 
Mann, M. (1984), 'The autonomous power of the state: Its origins, mechanisms and results', European Journal of Sociology, 25 (2), 185-213.

Marston, A. (2019), 'Strata of the state: Resource nationalism and vertical territory in Bolivia', Political Geography, 74, 102-40.

Mayer, T. (2000), Gender Ironies of Nationalism: Sexing the Nation, New York: Routledge.

McCreary, T. and R. Milligan. (2014), 'Pipelines, permits, and protests: Carrier Sekani encounters with the Enbridge Northern Gateway Project', Cultural Geographies, 21 (1), 115-29.

McDowell, L. (1999), Gender, Identity and Place: Understanding Feminist Geographies, Minneapolis, MN: University of Minnesota Press.

Medby, I. (2018), 'Articulating state identity: "Peopling” the Arctic state', Political Geography, 62, $116-25$.

Mitchell, K., S. Marston and C. Katz (2003), 'Life's work: An introduction, review and critique', Antipode, 35, 415-42.

Mitchell, T. (1999), 'Society, economy, and the state effect', in G. Steinmetz (ed.), State/Culture: State-Formation after the Cultural Turn, Ithaca, NY: Cornell University Press, pp. 76-97.

Mitchell T. (2002), Rule of Experts: Egypt, Techno-Politics, Modernity, Berkeley, CA: University of California Press.

Moisio, S. (2008), 'From enmity to rivalry? Notes on national identity politics in competition states', Scottish Geographical Journal, 124 (1), 78-95.

Moisio, S. (2018a), Geopolitics of the Knowledge-Based Economy, London: Routledge.

Moisio, S. (2018b), 'Urbanizing the nation-state: Notes on the geopolitical growth of cities and city-regions', Urban Geography, 39 (9), 1421-5.

Moisio, S. (2018c), 'Towards geopolitical analysis of geoeconomic processes', Geopolitics, 23 (1), 22-9.

Moisio, S. (2019), 'Re-thinking geoeconomics: Towards a political geography of economic geographies', Geography Compass, 13 (10), e12466.

Moisio, S. and J. Luukkonen (2017), 'Notes on spatial transformation in post-Cold War Europe and the territory work of the European Union', in P. Vihalemm, A. Masso and S. Operman (eds), The Routledge International Handbook of European Social Transformations, London: Routledge, pp. 224-38.

Moisio, S. and U. Rossi (2020), 'The start-up state: Governing urbanised capitalism', Environment and Planning A: Economy and Space, 52 (3), 532-52.

Mountz, A. (2003), 'Human smuggling, the transnational imaginary, and everyday geographies of the nation-state', Antipode, 35 (3), 622-44.

Mullings, B. (2012), 'Governmentality, diaspora assemblages and the ongoing challenge of "development", Antipode, 44 (2), 406-27.

Murphy, A.B. (2013), 'Territory's continuing allure', Annals of the Association of American Geographers, $103(5), 1212-26$.

Murray, R. (1971), 'The internationalization of capital and the nation-state', New Left Review, 67, $84-108$.

Naylor, L., M. Daigle, S. Zaragocin, M. Ramírez and M. Gilmartin (2018), 'Interventions: Bringing the decolonial to political geography', Political Geography, 66, 199-209.

Neves Alves, S. (2019), 'Everyday states and water infrastructure: Insights from a small secondary city in Africa, Bafatá in Guinea-Bissau', Environment and Planning C: Politics and Space, https://doi.org/ $10.1177 / 2399654419875748$

Nicol, H. (2017), 'From territory to rights: New foundations for conceptualising Indigenous sovereignty', Geopolitics, 22 (4), 794-814.

Norman, E. (2014), Governing Transboundary Waters: Canada, the United States and Indigenous Communities, New York: Routledge.

Ó Tuathail, G. (2010), 'Localizing geopolitics: Disaggregating violence and return in conflict regions', Political Geography, 29 (5), 256-65.

Offe, C. and V. Ronge (1982), 'Theses on the theory of the state', in A. Giddens and D. Held (eds), Classes, Power, and Conflict, Berkeley, CA: University of California Press, pp. 249-56.

Ohmae, K. (1993), "The rise of the "region state", Foreign Affairs, 72, 78-87.

Ohmae K. (1995), The Borderless World: Power and Strategy in the Interlinked Economy, New York: Harper Business. 
Olds, K. (2001), Globalization and Urban Change: Capital, Culture, and Pacific Rim Mega-Projects, Oxford: Oxford University Press.

O'Lear, S. (ed.) (2020), A Research Agenda for Environmental Geopolitics, Cheltenham, UK and Northampton, MA, USA: Edward Elgar Publishing.

Ong, A. (2006), Neoliberalism as Exception: Mutations in Citizenship and Sovereignty, Durham, NC: Duke University Press.

Paasi, A. (1996), Territories, Boundaries, and Consciousness: The Changing Geographies of the Finnish-Russian Boundary, New York: J. Wiley \& Sons.

Painter, J. (2006), 'Prosaic geographies of stateness', Political Geography, 25 (7), 752-74.

Painter J. (2010), 'Rethinking territory', Antipode, 42, 1090-118.

Parker, W.H. (1982), Mackinder: Geography as an Aid to Statecraft, Oxford: Clarendon Press.

Peck, J. and A. Tickell (1992), 'Local modes of social regulation: Regulation theory, Thatcherism, and uneven development', Geoforum, 23 (3), 347-63.

Peck, J. and A. Tickell (2002), 'Neoliberalizing space', Antipode, 34, 380-404.

Phelps, N.A. and J.T. Miao (2020), 'Varieties of urban entrepreneurialism', Dialogues in Human Geography, https://doi.org/10.1177/2043820619890438

Piketty, T. (2019), Capital and Ideology, Cambridge, MA: Harvard University Press.

Pinder, D. (2005), Visions of the City: Utopianism, Power and Politics in Twentieth-Century Urbanism, New York: Routledge.

Poulantzas N. (1978), State, Power, Socialism, London: New Left Books.

Prokkola, E.-K. and J. Ridanpää (2015), 'Border guarding and the politics of the body: An examination of the Finnish Border Guard Service', Gender, Place and Culture, 22 (10), 1374-90.

Quinn, J. (2017), 'Gatekhili mountains, Gatekhili state: Fractured alpine forest governance and post-Soviet development in the Republic of Georgia', Journal of Alpine Research/Revue de Géographie Alpine, 105 (1), 1-14.

Radice H. (1984), 'The national economy: A Keynesian myth?', Capital and Class, 8, 111-40.

Rogers, D. (2015), The Depths of Russia: Oil, Power, and Culture after Socialism, Ithaca, NY: Cornell University Press.

Rose-Redwood, R. (2012), 'With numbers in place: Security, territory, and the production of calculable space', Annals of the Association of American Geographers, 102 (2), 295-319.

Rossi, U. (2017), Cities in Global Capitalism, Cambridge: Polity.

Routledge, P., A. Cumbers and K. Derickson (2018), 'States of just transition: Realising climate justice through and against the state', Geoforum, 88, 78-86.

Sanyal, R. (2018), 'Managing through ad hoc measures: Syrian refugees and the politics of waiting in Lebanon', Political Geography, 66 (1), 67-75.

Sassen S. (2013), 'When territory deborders territoriality', Territory, Politics, Governance, 1, 21-45.

Scott, A. (1988), Metropolis: From the Division of Labour to Urban Form, Berkeley, CA: University of California Press.

Secor, A. (2007), 'Between longing and despair: State, space, and subjectivity in Turkey', Environment and Planning D: Society and Space, 25 (1), 33-52.

Sharma, A. and A. Gupta (2006), 'Introduction: Rethinking theories of the state in an age of globalization', in A. Sharma and A. Gupta (eds), The Anthropology of the State: A Reader, Oxford: Blackwell, pp. $1-41$.

Sharp, J. (2000), 'Remasculinising geo-politics? Comments on Gearóid O'Tuathail's Critical Geopolitics', Political Geography, 19 (3), 361-4.

Sharp, J. (2007), 'Embodying the state and citizenship', Geoforum, 38 (4), 602-4.

Smith, S. (2020), Intimate Geopolitics: Love, Territory, and the Future on India's Northern Threshold, New Brunswick, NJ: Rutgers University Press.

Staeheli, L., E. Kofman and L. Peake (eds) (2004), Mapping Women, Making Politics: Feminist Perspectives on Political Geography, New York: Routledge.

Staeheli L., P. Ehrkamp, H. Leitner and C. Nagel (2012), 'Dreaming the ordinary: Daily life and the complex geographies of citizenship', Progress in Human Geography, 36 (5), 628-44.

Stein, S. (2019), Capital City: Gentrification and the Real Estate State, London: Verso.

Storper M. (2013), Keys to the City: How Economics, Institutions, Social Interaction, and Politics Shape Development, Princeton, NJ: Princeton University Press. 
Taylor, P.J. (1982), ‘A materialist framework for political geography', Transactions of the Institute of British Geographers, 7, 15-34.

Taylor, P.J. (2003), 'Radical political geographies', in J. Agnew, K. Mitchell and G. Toal (eds), A Companion to Political Geography, Oxford: Blackwell, pp. 47-58.

Tynen, S. (2020), 'State territorialization through Shequ community centres: Bureaucratic confusion in Xinjiang, China', Territory, Politics, Governance, 8 (1), 7-22.

Tyner, J. (2018), The Politics of Lists: Bureaucracy and Genocide under the Khmer Rouge, Morgantown, VA: West Virginia University Press.

Velednitsky, S., S. Hughes and R. Machold (2020), 'Political geographical perspectives on settler colonialism', Geography Compass, e12490, https://doi.org/10.1111/gec3.12490

While, A., A.E.G. Jonas and D. Gibbs (2010), 'From sustainable development to carbon control: The eco-restructuring of the state and the politics of urban and regional development', Transactions Institute of British Geographers, 35, 76-93.

Whitehead, M., R. Jones and M. Jones (2007), The Nature of the State: Excavating the Political Ecologies of the Modern State, Oxford: Oxford University Press.

Whittlesey, D. (1939), The Earth and the State, New York: Henry Holt.

Whyte, K. (2018), 'Indigenous science (fiction) for the Anthropocene: Ancestral dystopias and fantasies of climate change crises', Environment and Planning E: Nature and Space, 1 (1-2), 224-42.

Williams, J. and G.A. Boyce (2013), 'Fear, loathing, and the everyday geopolitics of encounter', Geopolitics, 18 (4), 895-916.

Winders, J. and B. Smith (2019), 'Social reproduction and capitalist production: A genealogy of dominant imaginaries', Progress in Human Geography, 43 (5), 871-89.

Wissen M. and U. Brand (2010), 'Approaching the internationalization of the state: An introduction', Antipode, 43, 1-11.

Woodward, K. (2014), 'Affect, state theory, and the politics of confusion', Political Geography, 41, $21-31$.

Woodward, R. (2000), 'Warrior heroes and little green men: Soldiers, military training and the construction of rural masculinities', Rural Sociology, 65 (4), 640-57.

Yuval-Davis, N. (1997), Gender \& Nation, London: Sage.

Zhou, Y. (2015), 'State power and environmental initiatives in China: Analyzing China's Green Building program through an ecological modernization perspective', Geoforum, 61, 1-12.

Zuboff, S. (2019), The Age of Surveillance Capitalism, New York: Public Affairs. 